\title{
Chitosan-Cu-salen/Carbon Nano-Composite Based Electrode for the Enzyme-less Electrochemical Sensing of Hydrogen Peroxide
}

\author{
Harishchandra Digambar Jirimali ${ }^{1,2 *}$, Duraisamy Saravanakumar ${ }^{1,3}$, and Woonsup Shin ${ }^{1 *}$ \\ ${ }^{1}$ Department of Chemistry and Interdisciplinary Program of Integrated Biotechnology, Sogang University, Seoul 121-742 \\ Republic of Korea \\ ${ }^{2}$ School of Chemical Sciences, North Maharashtra University, Jalgaon (MS) 425001 India \\ ${ }^{3}$ Department of Chemistry, School of Advanced Sciences, VIT University, Vellore-632014, India
}

\begin{abstract}
$\mathrm{Cu}-$ Salen complex was prepared and attached into chitosan (Cs) polymer backbone. Nanocomposite of the synthesized polymer was prepared with functionalized carbon nano-particles $(\mathrm{Cs}-\mathrm{Cu}-\mathrm{sal} / \mathrm{C})$ to modify the electrode surface. The surface morphology of (Cs-Cu-sal/C) nanocomposite film showed a homogeneous distribution of carbon nanoparticles within the polymeric matrix. The cyclic voltammogram of the modified electrode exhibited a redox behavior at $-0.1 \mathrm{~V} v \mathrm{vs} . \mathrm{Ag} / \mathrm{AgCl}$ $(3 \mathrm{M} \mathrm{KCl})$ in $0.1 \mathrm{M} \mathrm{PB}(\mathrm{pH} 7)$ and showed an excellent hydrogen peroxide reduction activity. The $\mathrm{Cs}-\mathrm{Cu}$-sal/C electrode displays a linear response from $5 \times 10^{-6}$ to $5 \times 10^{-4} \mathrm{M}$, with a correlation coefficient of 0.993 and detection limit of $0.9 \mu \mathrm{M}$

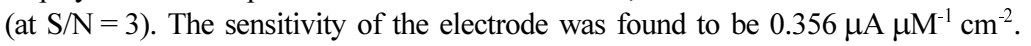

Keywords : Electrochemical sensor, Hydrogen peroxide, Chitosan, Copper complex, Polymer nano-composite

Received : 10 November 2017, Accepted : 21 April 2018

\section{Introduction}

Electrode modifications with redox-active moieties or a functional groups has gain a great interest, due to their fundamental importance in electrochemical catalysis and bio-sensing where transition metal complexes are used as an electro-catalyst due to their tunable redox potential [1-3]. Tetra dentate Schiff base ligands have been extensively used as catalysts in organic reactions and bio-mimetic enzymatic reactions $[4,5]$. Salen based electro-active complexes and their polymers have potential applications in the field of electro-catalysts, chemical sensors and optical devices [6,7]. The metal complexes are often coated on the electrode surfaces either by electro-deposition or immobilizing them with polymer matrix for the catalytic purposes[8-10]. Copper complexes of salentype ligands are important in some biochemical pro-

*E-mail address: shinws@sogang.ac.kr, hdj739@gmail.com DOI: https://doi.org/10.5229/JECST.2018.9.3.169 cesses, and DNA cleavage and antimicrobial activity [11-14]. Cu-salen complexes and metal organic frame work have been prepared and their properties had been studied well [15-17].

Chitosan is an amino-polysaccharide prepared by deacetylation of chitin, which is discarded as industrial waste so it can be considered as a low cost and nonhazardous polymer $[18,19]$. Chitosan bears free amine groups which are used for the immobilization of the metal complexes and redox mediators [20-23]. Currently, much attention has been focused on developing new nano-materials, which are used for signal amplification in electrochemical methods [24]. Conducting nanomaterials with a larger surface area are the potential candidates for biomolecules immobilization and signal amplifications [25]. Among the available materials used, carbon nano-materials are the most exciting because of their unique physical, chemical and mechanical properties [26,27].

Hydrogen peroxide is a vital compound in the biological transformations also widely used in several 
fields like food production and chemical industries, therefore, determination of hydrogen peroxide becomes an important task in the field of biosensor development [28]. Number of methods have been established for the detection of hydrogen peroxide $[29,30]$. The electrochemical sensors developed by immobilizations of enzymes and mediators are also employed for detection of hydrogen peroxide [31]. Electrodes modified with the transition metal hexaferrocynates and metal oxides were used for the direct electro-catalytic sensing of $\mathrm{H}_{2} \mathrm{O}_{2}[32,33]$. Recently, the synthesis of a new bimetallic metalloporphyrinic framework of $\mathrm{Cu}(\mathrm{II})$ complex and its electrochemical application for the hydrogen peroxide detection has been reported [34].

The present work describes the synthesis of $\mathrm{Cu}$ salen coordinated chitosan polymer (Cs-Cu-sal). Redox active nano-composite of Cs-Cu-sal was prepared by simple mixing with functionalized carbon nanoparticles. $\mathrm{Cs}-\mathrm{Cu}-\mathrm{sal} / \mathrm{C}$ composite was drop coated on the printed carbon electrodes and these modified electrodes were tested for $\mathrm{H}_{2} \mathrm{O}_{2}$ sensing by cyclic voltammetric and i-t curve techniques. The Cs$\mathrm{Cu}$-sal/C electrode showed the sensitivity of

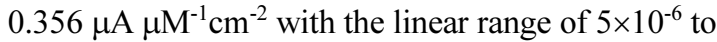
$5 \times 10^{-4} \mathrm{M}$ for the hydrogen peroxide sensing.

\section{Experimental}

\subsection{Reagents}

Chitosan (lower mol. wt.), copper(II)acetate monohydrate, ethylene diamine, 2-hydroxy benzaldehyde, acetic acid and hydrogen peroxide were obtained from Sigma Aldrich and membrane filters from the Millipore. All the chemicals were of analytical grades and used without further purification. Water purified from Millipore system was used in all the experiments. 0.1 M phosphate buffer ( $\mathrm{pH}$ 7.0) solution was prepared with $\mathrm{Na}_{2} \mathrm{HPO}_{4}$ and $\mathrm{NaH}_{2} \mathrm{PO}_{4}$.

\subsection{Surface characterizations}

The surface morphology of the composite film on a printed carbon electrode was recorded with the use of a field emission scanning electron microscope, Hitachi S-4300 at $15 \mathrm{KV}$.

\subsection{Electrochemical experiments}

Cyclic voltammetry was performed with printed carbon electrode (PCE, 5 mm, SE100, Zensar R \&
$\mathrm{D}$, Taiwan) as working, $\mathrm{Ag} / \mathrm{AgCl}(3 \mathrm{M} \mathrm{KCl})$ as reference and platinum wire as counter electrodes. All the experiments were performed in $0.1 \mathrm{M}$ phosphate buffer at $\mathrm{pH} 7$ under argon atmosphere at the room temperature. CHI 900 potentiostat $(\mathrm{CH}$ Instruments, USA) was used for electrochemical measurements.

\subsection{Synthesis of Cs-Cu-sal Polymer}

2.4.1 Preparation of the salen ligand

Ethylenediamine $(60 \mathrm{mg})$ and salicylaldehyde $(244 \mathrm{mg})$ in 1:2 molar ratio were added in ethanol and the mixture was heated to reflux for $1 \mathrm{~h}$. Bright yellow crystalline solid of salen [N,N-ethylenebis(salicylidene-aminato)] ligand was formed which was collected by filtration and washed thoroughly with ethanol.

\subsubsection{Neat $\mathrm{Cu}$-salen complex}

Solution of $\mathrm{Cu}\left(\mathrm{CH}_{3} \mathrm{COOH}\right)(181 \mathrm{mg})$ in $10 \mathrm{~mL}$ (methanol:water; 7:3 v/v) was added slowly to salen $(272 \mathrm{mg}$ ) in $15 \mathrm{~mL}$ methanol under stirring at room temperature. The resulting mixture was heated to reflux at $80^{\circ} \mathrm{C}$ for $1 \mathrm{~h}$ and the solid complex formed was isolated by filtration. The dark green crystals of $\mathrm{Cu}$-salen complex thoroughly washed with methanol and dried, which is referred as $\mathrm{Cu}$ (II)-salen.

\subsubsection{Cs-Cu-sal polymer}

$\mathrm{Neat} \mathrm{Cu}$-salen solution in methanol was added dropwise to $1 \%$ chitosan in $1 \%$ aqueous acetic acid and stirred overnight. The resulting $\mathrm{Cs}-\mathrm{Cu}$-sal was filtered through 10,000 molecular weight cut-off polycarbonate membrane to remove the low molecular weight polymer. The obtained polymer was precipitated with acetone, collected and dried under the vacuum.

\subsection{Treatment of carbon}

Commercially available carbon black (C) powder was treated with acid as per earlier reported procedure [20]. The carbon black powder was boiled in $5 \mathrm{M} \mathrm{HNO}_{3}$ for a shorter time, filtered and repeatedly washed with deionized water. Functionalized carbon black was dried and used for the $\mathrm{Cs}-\mathrm{Cu}$-sal polymer nano-composite preparation.

\subsection{Preparation of electrodes}

$200 \mu \mathrm{L}$ of $1 \% \mathrm{Cs}-\mathrm{Cu}$-sal polymer in $1 \%$ acetic acid 


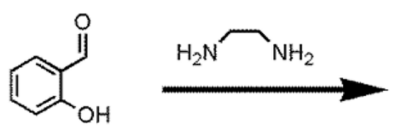

(n)

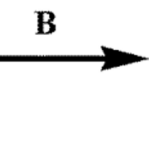

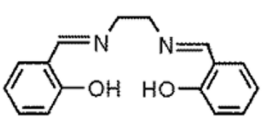

A

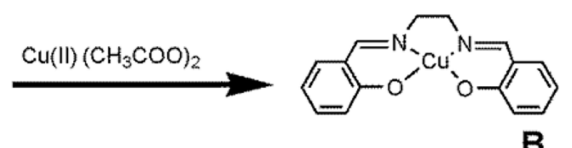

B

Scheme 1. Synthesis of Cs-Cu-sal polymer.

$(10 \mathrm{mg} / \mathrm{mL})$ and $2 \mathrm{mg}$ of acid treated carbon $(\mathrm{C})$ powder were mixed and sonicated for 1 minute. $2 \mu \mathrm{L}$ of this $\mathrm{Cs}-\mathrm{Cu}$-sal/C composite material was drop coated on the PCE. Air dried electrodes were washed with water and used for the further electrochemical and other characterization.

\section{Results and Discussion}

$\mathrm{Cs}-\mathrm{Cu}$-sal polymer was synthesized in two steps procedure as presented in Scheme 1. In the first step, $\mathrm{Cu}$-salen complex was prepared by mixing salen ligand and $\mathrm{Cu}$ acetate in methanol : water solvent. The chitosan polymer was modified with $\mathrm{Cu}-\mathrm{Sal}$ complex by simple mixing of $1 \%$ chitosan in $1 \%$ acetic acid solution with the metal complex. The composite of the $\mathrm{Cu}$ complex attached polymer with functionalized carbon nano powder was prepared by mixing them and sonication. The PCEs were modified by drop coating of $\mathrm{Cs}-\mathrm{Cu}-\mathrm{sal} / \mathrm{C}$ and dried it at room temperature.

Fig. 1(A) showed the SEM image of Cs-Cu-sal/C polymer composite film and Fig. 1(B) showed the image of the pristine carbon nanoparticles. The sizes of the pristine carbon particles and the carbon particles embedded in the polymer composite were observed in the range of 50 to $100 \mathrm{~nm}$. The functionalized carbon particles having slightly negative charge and Cs-Cu-sal polymer having slightly positive charge in acidic $\mathrm{pH}$ due to the protonation of the free amines of the chitosan polymer. The polymer composite was prepared by sonication of functionalized carbon and polymer in the solution, the polymer with positive charge can form the thin film on the negatively charge high surface area carbon particles.
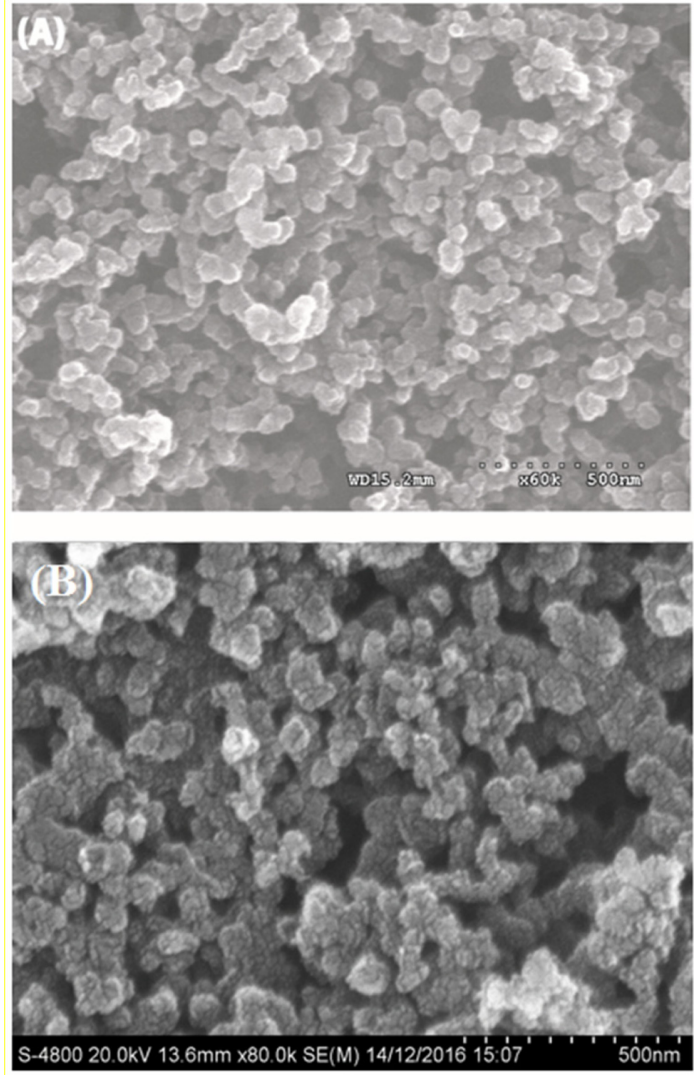

Fig. 1. SEM images of Cs-Cu-sal/C modified PCE surface view (A) and pristine carbon particles (B).

The homogeneous distribution of the carbon particles in the polymer produces a three dimensional homogeneous porous film and the presence of polymer was in the composite was supported by the electrochemical characterizations. 
(A)

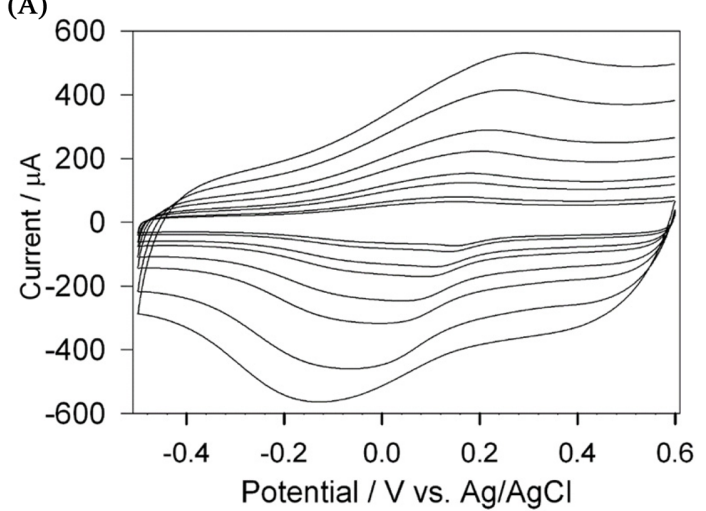

(B)

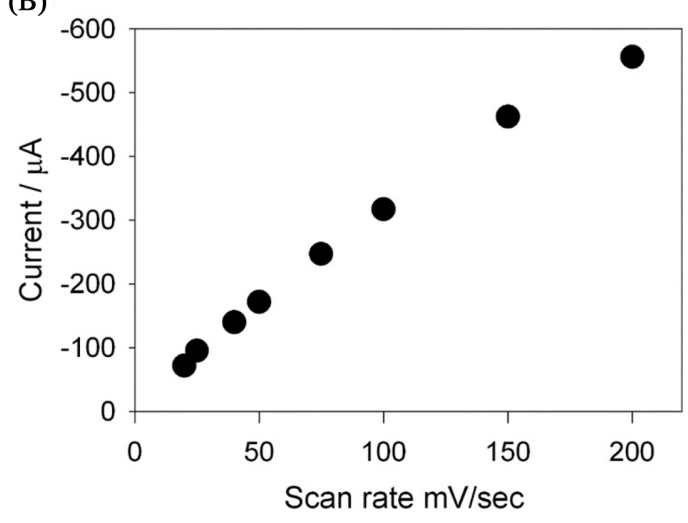

Fig. 2. Cyclic voltammograms of the $\mathrm{Cs}-\mathrm{Cu}-\mathrm{salen} / \mathrm{C}$ composite electrode in $0.1 \mathrm{M}$ phosphate buffer at the scan rates of $20 \mathrm{mV} / \mathrm{sec}$ to $200 \mathrm{mV} / \mathrm{sec}$ (A) and plot of scan rate vs. current (B).

\subsection{Electrochemical characterization of $\mathrm{Cs}-\mathrm{Cu}-\mathrm{sal} / \mathrm{C}$}

The cyclic voltammogram of $\mathrm{Cs}-\mathrm{Cu}-\mathrm{sal} / \mathrm{C}$ electrode was recorded in $0.1 \mathrm{M}$ phosphate buffer $(\mathrm{pH} 7)$ under Ar, shown in Fig. 2(A). The modified electrode exhibited a set of redox peaks at $0.15 \mathrm{~V}$ and $0.17 \mathrm{~V}$ at the scan rate of $50 \mathrm{mV} / \mathrm{s}$ due to $\mathrm{Cu}(\mathrm{II})$ to $\mathrm{Cu}(\mathrm{I})$ couple [35]. The overlay of the cyclic voltammograms of Cs-Cu-sal/C film at scan rate of $10 \mathrm{mV} /$ $\mathrm{s}$ to $200 \mathrm{mV} / \mathrm{s}$ indicated that the redox peak current and peak to peak separation were linearly increased with the increased in scan rate. Fig. 2(B) showed the linear dependence of the redox peak current to the scan rate, suggested that the charge transport through the film occurs under the surface confined phenomenon of electron transfer at $\mathrm{Cs}-\mathrm{Cu}-\mathrm{sal} / \mathrm{C}$ electrode. Similar behavior was reported by Van Bui , for the ferrocene brushes modified electrodes [36]. This newly prepared $\mathrm{Cs}-\mathrm{Cu}$-sal/C film showed ade-

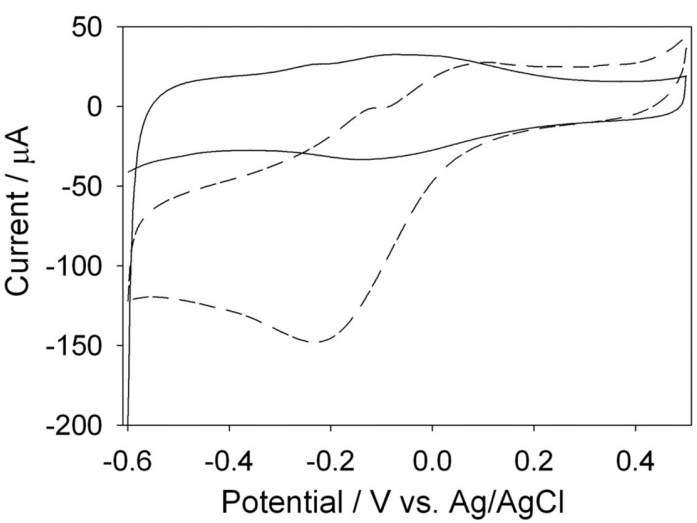

Fig. 3. Cyclic voltammograms of $\mathrm{Cs}-\mathrm{Cu}-\mathrm{sal} / \mathrm{C}$ modified PCE in $0.1 \mathrm{M}$ phosphate buffer (solid line) and phosphate buffer with $5 \mathrm{mM} \mathrm{H}_{2} \mathrm{O}_{2}$ (dash line) at $10 \mathrm{mV} / \mathrm{sec}$.

quate stability in the aqueous solutions as the current of the peaks are not decreased on continuous cycles.

\subsection{Electrocatalytic effect on reduction of hydrogen peroxide}

The usefulness of the $\mathrm{Cs}-\mathrm{Cu}$-sal modified electrode for $\mathrm{H}_{2} \mathrm{O}_{2}$ sensing was further demonstrated by cyclic voltammetry. Cyclic voltammograms of the modified electrode were recorded in $0.1 \mathrm{M} \mathrm{PB}$ at $\mathrm{pH} 7$ in the presence and absence of $5 \mathrm{mM} \mathrm{H}_{2} \mathrm{O}_{2}$ at the scan rate of $10 \mathrm{mV} / \mathrm{sec}$ (Fig. 3) under Ar. The current of the reduction peak of the $\mathrm{Cu}$ (II) to $\mathrm{Cu}$ (I) redox couple at $-200 \mathrm{mV}$ is increased in the presence of $5 \mathrm{mM}$ $\mathrm{H}_{2} \mathrm{O}_{2}$ (dashed line) indicating the hydrogen peroxide reduction. The reduction of the hydrogen peroxide and the possible reaction mechanism is proposed as follows.

$$
\begin{aligned}
& \mathrm{Cu}(\mathrm{II})-\mathrm{sal}+\mathrm{e}^{-} \rightarrow \mathrm{Cu}(\mathrm{I}) \text {-sal } \\
& 2 \mathrm{Cu}(\mathrm{I})-\mathrm{sal}+\mathrm{H}_{2} \mathrm{O}_{2}+2 \mathrm{H}^{+} \rightarrow 2 \mathrm{Cu}(\mathrm{II})-\mathrm{sal}+2 \mathrm{H}_{2} \mathrm{O}
\end{aligned}
$$

\subsection{Effect of scan rate and $\mathrm{pH}$}

Effect of scan rates $(v)$ on the sensing of $\mathrm{H}_{2} \mathrm{O}_{2}$ in terms of catalytic currents was investigated in the range of $10 \mathrm{mV} / \mathrm{s}$ to $80 \mathrm{mV} / \mathrm{s}$. Fig. 4(A) shows the $\mathrm{CVs}$ of the $\mathrm{Cs}-\mathrm{Cu}-\mathrm{sal} / \mathrm{C}$ at different scan rates in the potential window of -0.6 to $+0.5 \mathrm{~V}$ in PBS ( $\mathrm{pH} 7.0$ ). From Fig. 4(B), it can be observed that the cathodic peak currents varied linearly with the increase in scan rate and this indicates the surface confined electron 
(A)

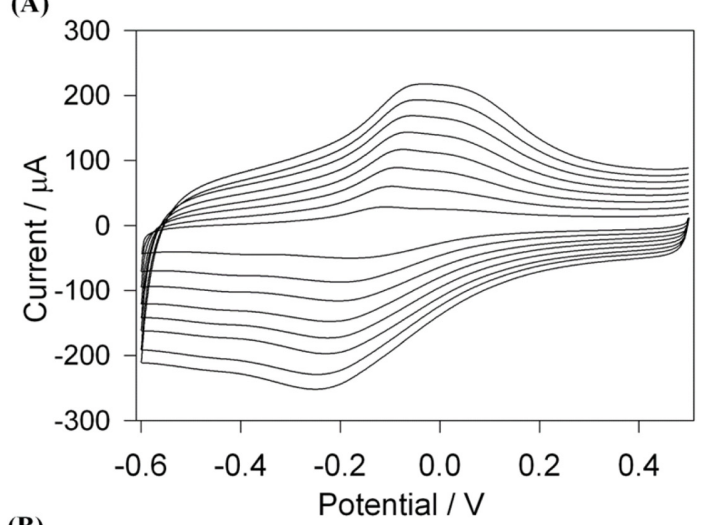

(B)

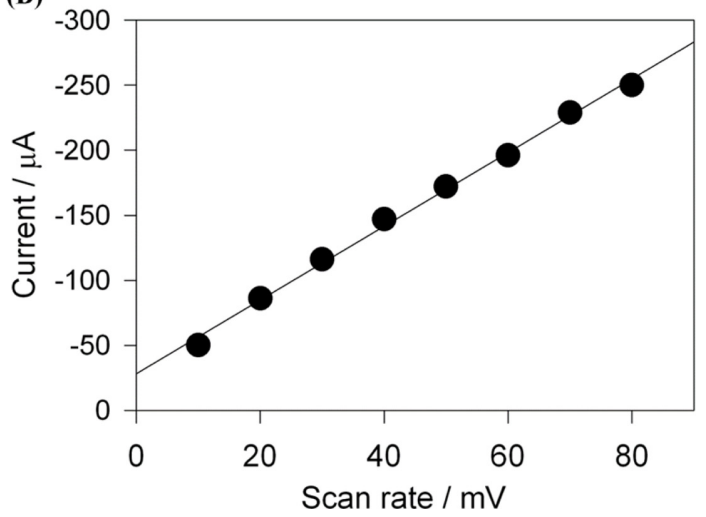

Fig. 4. Cyclic voltammograms of $\mathrm{Cs}-\mathrm{Cu}-\mathrm{sal} / \mathrm{C}$ modified PCE in $0.1 \mathrm{M}$ phosphate buffer containing $1 \mathrm{mM} \mathrm{H}_{2} \mathrm{O}_{2}$ at the scan rate of $10,20,30,40,50,60,70,80 \mathrm{mV} / \mathrm{sec}$ from inner to outer (A), and the cathodic peak current vs. scan rate $(\mathrm{B})$.

transfer at the $\mathrm{Cs}-\mathrm{Cu}$-sal/C modified electrode surface. The effect of $\mathrm{pH}$ on the $\mathrm{H}_{2} \mathrm{O}_{2}$ reduction also checked by $\mathrm{CV}$ in the $\mathrm{PB}$ with $\mathrm{pH}$ ranges from 5 to 9 (Fig. 5(A)). Hydrogen peroxide reduction potential was slightly shifted with $\mathrm{pH}$, while decreased in current was observed from $\mathrm{pH} 5$ to $\mathrm{pH} 9$ (Fig. 5(B)). The $\mathrm{H}_{2} \mathrm{O}_{2}$ reduction is the $\mathrm{H}^{+}$dependent process accordingly there is shifting of the potential occurred as th $\mathrm{pH}$ of the phosphate buffer changes from $\mathrm{pH} 5$ to $\mathrm{pH}$ 9 [37]. The modified electrode did not show significant change in the catalytic response when the $\mathrm{pH}$ was varied from 5 to 9 (variation in current response is within $5 \mu \mathrm{A}$ ). Though the modified electrode was stable in the investigated $\mathrm{pH}$ range, $\mathrm{pH} 7$ was chosen as the working $\mathrm{pH}$ for further experiments as neutral $\mathrm{pH}$ is preferable for analyzing $\mathrm{H}_{2} \mathrm{O}_{2}$ in biological samples.
(A)

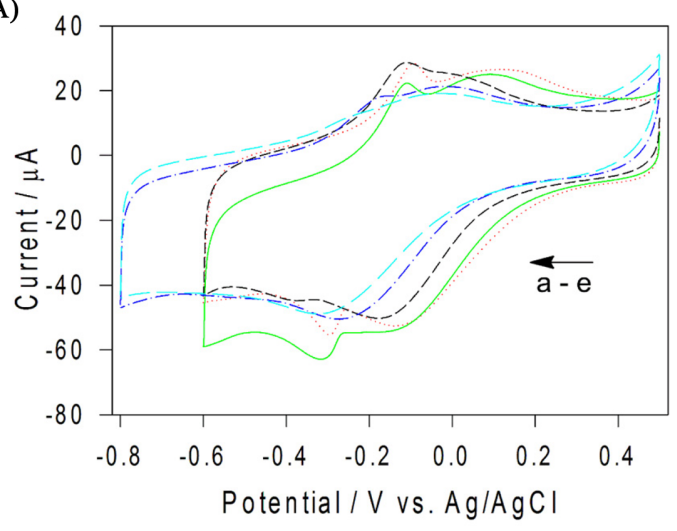

(B)

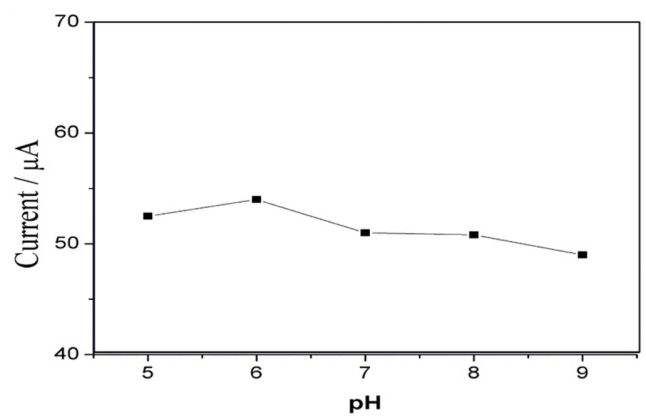

Fig. 5. Cyclic voltammograms of $\mathrm{Cs}-\mathrm{Cu}-\mathrm{sal} / \mathrm{C}$ modified PCE in $0.1 \mathrm{M}$ phosphate buffer containing $1 \mathrm{mM} \mathrm{H}_{2} \mathrm{O}_{2}$ in pH 5 (red), 6 (green), 7 (black), 8 (blue), and 9 (cyan blue) respectively (A) and plot of cathodic peak current vs. pH (B).

\subsection{Amperometric $\mathrm{H}_{2} \mathrm{O}_{2}$ detection}

The amperometric hydrogen peroxide sensing was studied by typical current-time response of the biosensor for successive additions of $\mathrm{H}_{2} \mathrm{O}_{2}$ in the continuously stirred PB at an applied potential of $-0.3 \mathrm{~V}$ under the optimized experimental conditions (Fig. 6 (A)). The rapid $\mathrm{H}_{2} \mathrm{O}_{2}$ response was achieved when the $\mathrm{H}_{2} \mathrm{O}_{2}$ was added in the stirred phosphate buffer solution and achieved $95 \%$ of steady-current in 5 seconds. The plot of the hydrogen peroxide concentration vs. amperometric current (Fig. 6(B)) showed the linear range of hydrogen peroxide concentration from $5 \times 10^{-6} \mathrm{M}$ to $5 \times 10^{-4} \mathrm{M}$ and the detection limit of $0.9 \mathrm{mM}$ with the sensitivity of $0.356 \mathrm{~mA} \mathrm{mM}^{-1} \mathrm{~cm}^{-2}$. The present sensor exhibits a comparable detection limit, linear detection range and higher sensitivity than the recently reported electrodes for the detection of hydrogen peroxide in neutral aqueous solutions $[34,35,38]$. 


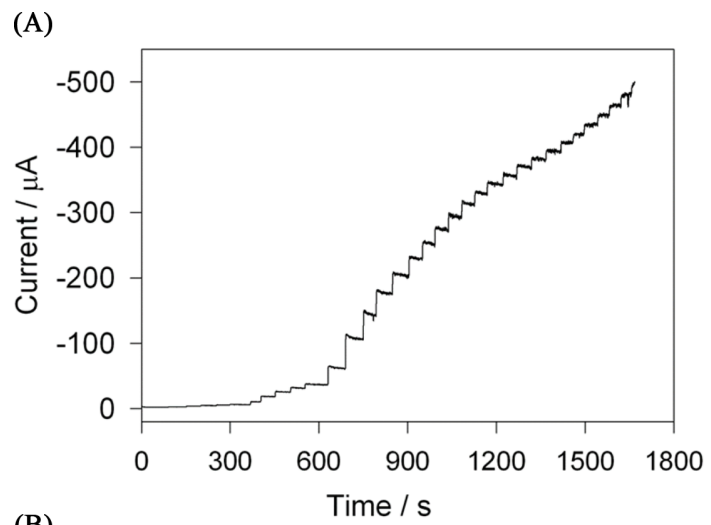

(B)

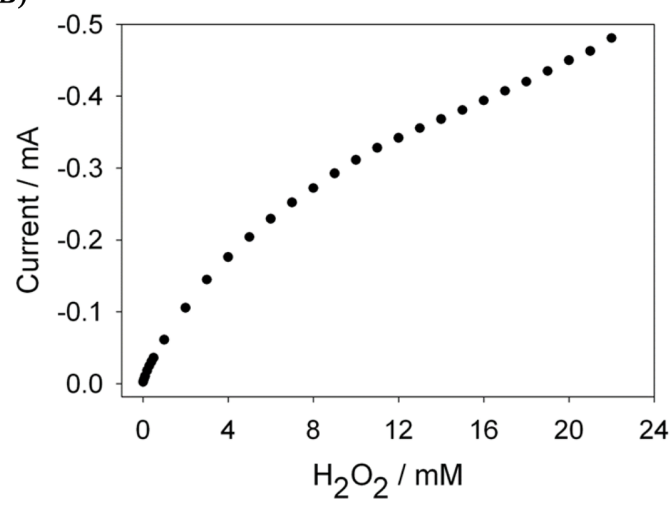

Fig. 6. (A) The steady state current time response of Cs$\mathrm{Cu}$-sal/C modified PCE with successive injection of the $\mathrm{H}_{2} \mathrm{O}_{2}$ in to a stirred $0.1 \mathrm{M}$ phosphate buffer at the applied potential of $-0.3 \mathrm{~V}$ and (B) The plot of the current response to $\mathrm{H}_{2} \mathrm{O}_{2}$ added.

\subsection{Effect of interferences and stability}

It is known that the nitrate and ascorbic acid can be electrochemically reduced at the negative potential as of hydrogen peroxide and considered as an interference in the hydrogen peroxide sensing [38,39]. The effect of the interfering nitrate and ascorbic acid was examined by amperometric analysis. Fig. 7 shows the amperometric i-t curve at $\mathrm{Cs}-\mathrm{Cu}$-sal/C modified electrode in stirred phosphate buffer. Addition of $0.5 \mathrm{mM}$ of $\mathrm{H}_{2} \mathrm{O}_{2}$ showed instant increase in the current (a) and followed by the addition equimolar ascorbic acid (b) and nitrate (c) solutions didn't cause any effect on $\mathrm{H}_{2} \mathrm{O}_{2}$ peak current. The stability of the modified electrode was tested by subjecting to potential cycling in the presence and absence of $\mathrm{H}_{2} \mathrm{O}_{2}$. The modified electrode shown $5 \%$ relative decrease in peak current after 50 cycles in the absence of $\mathrm{H}_{2} \mathrm{O}_{2}$, while it exhibited $7.4 \%$ decrease in current response in the pres-

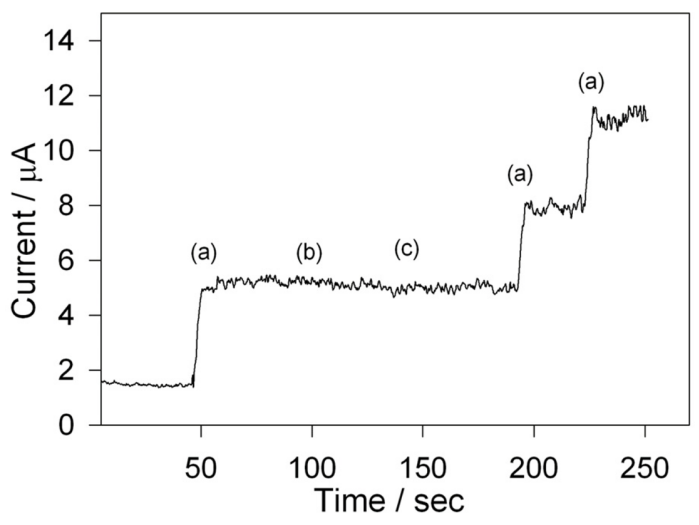

Fig. 7. Effect of ascorbic acid (b) and nitrite (c) on the determination of $\mathrm{H}_{2} \mathrm{O}_{2}$ (a) with $\mathrm{Cs}-\mathrm{Cu}$-sal/C electrode in $0.1 \mathrm{M}$ phosphate buffer $\mathrm{pH} 7$ at an applied potential of $-0.3 \mathrm{~V}$.

ence of $\mathrm{H}_{2} \mathrm{O}_{2}$. The stability data indicates the usefulness of the present electrode in the detection of hydrogen peroxide.

\section{Conclusions}

Cs-Cu-sal polymer and it's composite with carbon nanoparticles were prepared. The composite film on the PCE electrodes was prepared by drop coating method. The modified electrodes was characterized and tested for the hydrogen peroxide sensing in neutral aqueous solutions. Method of sensor preparation and all the experimental results suggesting that the proposed electrode could be used for electrocatalytic $\mathrm{H}_{2} \mathrm{O}_{2}$ detection in real samples.

\section{Acknowledgement}

This research was supported by the Nextgeneration Medical Device Development Program for Newly-Created Market of the National Research Foundation (NRF) funded by the Korean government, MSIP (NRF-2015M3D5A1065760) to WS. HDJ is thankful to Science and Engineering Research Board (SERB), Government of India for the startup research grant (file no. SB/FT/CS-0372014).

\section{References}

[1] M. Tavakkoli, M. Nosek, J. Sainio, F. Davodi, T. Kallio, P. Joensuu, ACS-Catalysis, 2017, 7(12), 8033-8041. 
[2] P. Gayathri, A. Senthil Kumar, Langmuir, 2014, 30(34), 10513-10521.

[3] D. Saravanakumar, J. Song, N. Jung, H. Jirimali, W. Shin, Chem. Sus. Chem., 2012, 5(4), 634-636.

[4] R.F. Munhá, R.A. Zarkesh, A.F. Heyduk, Inorg. Chem., 2013, 52(19), 11244-11255.

[5] D. Saravanakumar, R.K. Nagarale, H.C. Jirimali, J.M. Lee, J. Song, J. Lee, W. Shin, J. Electrochem. Sci. Technol., 2016, 7(4), 298-305.

[6] V. V. Sizov, M. V. Novozhilova, E. V. Alekseeva, M.P. Karushev, A.M. Timonov, S.N. Eliseeva, A.A. Vanin, V. V. Malev, O. V. Levin, J. Solid State Electrochem., 2014, 19(2), 453-468.

[7] A. Branco, C. Pinheiro, J. Fonseca, J. Tedim, A. Carneiro, A.J. Parola, C. Freire, F. Pina, Electrochem. Solid-State Lett., 2010, 13, 453-468.

[8] J.L. Li, F. Gao, Y.K. Zhang, F.Y. Kang, X.D. Wang, F. Ye, J. Yang, Sci. China Chem., 2012, 55(7), 1338-1344.

[9] H.D. Jirimali, R.K. Nagarale, J.M. Lee, D. Saravanakumar, W. Shin, Chem. Phys. Chem., 2013, 14(10), 2232-2236.

[10] H. Chen, Z. Sun, X. Liu, A. Han, P. Du, J. Phys. Chem. C., 2015, 119(17), 8998-9004.

[11] R.I. Kureshy, A. Das, N.U.H. Khan, S.H.R. Abdi, H.C. Bajaj, ACS Catal., 2011, 1, 1529-1535.

[12] P.J.K. Inba, B. Annaraj, S. Thalamuthu, M.A. Neelakantan, Bioinorg. Chem. appl., 2013, 439848, 1-11.

[13] X.-M. Xu, Z.-W. Mao, L.-N. Ji, J.-H. Yao, H. Li, Transit. Met. Chem., 2004, 29(6), 658-662.

[14] S.S. Tajudeen, G. Kannappan, Indian J. Adv. Chem. Sci., 2016, 4(1), 40-48.

[15] Y. Liu, Z. Li, G. Yuan, Q. Xia, C. Yuan, Y. Cui, Inorg. Chem., 2016, 55(24), 12500-12503.

[16] Z.N. Kadhim, J. Mater. Environ. Sci., 2015, 6(3), 693698.

[17] P.A. Mardini Farias, M.B. Rodrigues Bastos, Int. J. Electrochem. Sci., 2009, 4(3), 458-470.

[18] P. Kumar Dutta, J. Dutta, V.S. Tripathi, J. Sci. Ind. Res., 2004, 63, 20-31.

[19] J. Araki, Y. Yamanaka, K. Ohkawa, Polym. J., 2012, 44(7), 713-717.

[20] H.D. Jirimali, D. Saravanakumar, W. Shin, Bull. Korean Chem. Soc., 2015, 36(4), 1289-1291.
[21] Y. Wang, A. Pitto-Barry, A. Habtemariam, I. RomeroCanelon, P.J. Sadler, N.P.E. Barry, Inorg. Chem. Front., 2016, 3(8), 1058-1064.

[22] H.D. Jirimali, R.K. Nagarale, D. Saravanakumar, J.M. Lee, W. Shin, Carbohydr. Polym., 2013, 92(1), 641-644.

[23] N. Beden, H. Jirimali, W. Shin, R. Ludwig, C.K. Peterbauer, Insights Anal Electrochem., 2015, 1, 1-7.

[24] R. Khalil, S. Homaeigohar, D. Häußler, M. Elbahri, Nat. Report., 2016, 1-10.

[25] J.Y. Wang, L.C. Chen, K.C. Ho, ACS Appl. Mater. Interfaces., 2013, 5(16), 7852-7861.

[26] T. Tamaki, A. Hiraide, F.B. Asmat, H. Ohashi, T. Ito, T. Yamaguchi, Ind. Eng. Chem. Res., 2010, 49(14), 63946398.

[27] W. Putzbach, N.J. Ronkainen, Sensors, 2013, 13(4), 4811-4840.

[28] M.I. González-Sánchez, L. González-Macia, M.T. Pérez-Prior, E. Valero, J. Hancock, A.J. Killard, Plant, Cell Environ., 2013, 36(4), 869-878.

[29] M. Song, J. Wang, B. Chen, L. Wang, A Facile, Anal. Chem., 2017.

[30] X. Tan, J. Zhang, S. Tan, D. Zhao, Z. Huang, Y. Mi, Z. Huang, Electroanalysis., 2009, 21(13), 1514-1520.

[31] H.D. Jirimali, R.K. Nagarale, J.M. Lee, D. Saravanakumar, W. Shin, Electroanalysis., 2011, 23(9), 109-2115.

[32] T.-H. Tsai, T.-W. Chen, S.-M. Chen, K.C. Lin, Int. J. Electrochem Sci., 2011, 6, 4628-4637.

[33] L. Li, Z. Du, S. Liu, Q. Hao, Y. Wang, Q. Li, T. Wang, Talanta, 2010, 82(5), 1637-1641.

[34] L.-M. Shi, J.-X. Pan, B. Zhou, X. Jiang, J. Mater. Chem. B., 2015, 3(48), 9340-9348.

[35] S. Mahadevan, M. Palaniandavar, Inorg. Chem., 1998, 37(4), 693-700.

[36] V. Bui-Thi-Tuyet, G. Trippé-Allard, J. Ghilane, H. Randriamahazaka, ACS Appl. Mater. Interfaces., 2016, 8(42), 28316-28324.

[37] A. Salimi, M. Mahdioun, A. Noorbakhsh, A. Abdolmaleki, R. Ghavami, Electrochim. Acta, 2011, 56(9), 3387-3394.

[38] Z. Miao, D. Zhang, Q. Chen, Materials., 2014, 7(4), 2945-2955.

[39] N. Nasirizadeh, Z. Shekari, A. Nazari, M. Tabatabaee, $J$. Food Drug Anal., 2016, 24(1), 72-82. 